\title{
Commentary: Retrospective and prospective perspectives on zoonotic brucellosis
}

\author{
Cathy Kneipp ${ }^{1 *}$, Richard Malik ${ }^{2,3}$, Siobhan M. Mor ${ }^{4}$ and Anke K. Wiethoelter ${ }^{1}$ \\ ${ }^{1}$ Faculty of Veterinary and Agricultural Sciences, University of Melbourne, Melbourne, VIC, Australia, ${ }^{2}$ Centre for Veterinary \\ Education, University of Sydney, Sydney, NSW, Australia, ${ }^{3}$ School of Animal and Veterinary Sciences, Charles Sturt University, \\ Wagga Wagga, NSW, Australia, ${ }^{4}$ Institute of Infection and Global Health, University of Liverpool, Liverpool, United Kingdom
}

Keywords: Brucella, Brucellosis, Brucella canis, Australia, dog, fox, Brucella suis

\section{A Commentary on}

OPEN ACCESS

Edited by:

Lisa Sedger,

University of Technology

Sydney, Australia

Reviewed by:

Craig Godfrey,

James Cook University, Australia

Michael Philipp Reichel,

City University of Hong Kong,

Hong Kong

*Correspondence:

Cathy Kneipp

cathy.kneipp@student.unimelb.edu.au

Specialty section:

This article was submitted to Infectious Diseases,

a section of the journal

Frontiers in Microbiology

Received: 18 June 2019

Accepted: 29 July 2019

Published: 14 August 2019

Citation:

Kneipp C, Malik R, Mor SM and Wiethoelter AK (2019) Commentary:

Retrospective and prospective perspectives on zoonotic brucellosis.

Front. Microbiol. 10:1859.

doi: 10.3389/fmicb.2019.01859
Retrospective and prospective perspectives on zoonotic brucellosis

by Moreno, E. (2014). Front. Microbiol. 5:213. doi: 10.3389/fmicb.2014.00213

We are writing in response to the article by Moreno (2014) titled "Retrospective and prospective perspectives on zoonotic brucellosis", which contains two important errors regarding the status of Brucella canis in dogs and wildlife reservoirs of Brucella strains in Australia.

Moreno (2014) states "Canine brucellosis has just been recently found in domestic dogs in Australia” (page 7) citing Gardner and Reichel (1997) and Hofer et al. (2012). The article by Gardner and Reichel (1997) actually documents the absence of B. canis in the neighboring country of New Zealand, while Hofer et al. (2012) reported the first domestic detection of B. canis in a breeding kennel in Austria (Europe), not Australia. In fact, B. canis has never been reported in Australia or New Zealand (DAF, 2018a). We note that Australia has recently experienced a surge of cases of brucellosis in dogs, but these were caused by B. suis, not B. canis (Mor et al., 2016; James et al., 2017).

Moreno (2014) also states that "Brucella strains have been isolated in rodents and foxes in Australia” (page 7) citing Tiller et al. (2010) and Al Dahouk et al. (2012). No foxes from Australia were tested in these studies and there is no literature published to support detection of Brucella spp. in foxes in Australia. The article cited by Moreno (2014) to support evidence in foxes is Al Dahouk et al. (2012) which refers to another study by Scholz et al. (2009). The latter reports the isolation of B. microti from mandibular lymph nodes of red foxes (Vulpes vulpes) in Lower Austria (again, not Australia).

Strains of Brucella have been isolated from rodents in Australia. Tiller et al. (2010) re-examined Brucella strains collected by Cook et al. (1966) in North Queensland from three species of rodents, Rattus assimilis, Melomys cervinipes, and M. lutillus. These strains were originally reported as $B$. suis biovar 3 by Cook et al. (1966) but Tiller et al. (2010) "strongly" suggested they were a new atypical Brucella species. Wattam et al. (2012) subsequently found similarities between the atypical Australian rodent strains and two novel strains $\left(\mathrm{BO}^{\mathrm{T}}\right.$ and $\left.\mathrm{BO} 2\right)$ from atypical human infections.

Australia was declared free of B. abortus in 1989 after a long and successful eradication program and currently only two of the 10 well-characterized species of Brucella occur naturally in Australia. 
Specifically, B. ovis (non-zoonotic) is found only in sheep where it causes epididymal lesions and reproductive losses. Brucella suis biovar 1 is also endemic in feral pigs in certain regions and can be transmitted from feral pigs to humans and dogs (DAF, 2018a). The latter species is largely absent from the domestic swine herd in Australia (Rogers et al., 1989; DAF, 2018b).

To maintain Australia's status and international reputation of being free from other forms of brucellosis it is important

\section{REFERENCES}

Al Dahouk, S., Hofer, E., Tomaso, H., Vergnaud, G., Le Flèche, P., Cloeckaert, A., et al. (2012). Intraspecies biodiversity of the genetically homologous species Brucella microti. Appl. Environ. Microbiol. 78, 1534-1543. doi: 10.1128/AEM.06351-11

Cook, I., Campbell, R. W., and Barrow, G. (1966). Brucellosis in North Queensland rodents. Aust. Vet. J. 42, 5-8. doi: 10.1111/j.1751-0813.1966.tb04603.x

DAF, Q. G. (2018a). Brucellosis. Brisbane, QLD: Queensland Government Department of Agriculture and Fisheries Media. Retrieved from https://www. daf.qld.gov.au/business-priorities/animal-industries/animal-health-anddiseases/list/brucellosis

DAF, Q. G. (2018b). Swine Brucellosis. Brisbane, QLD: Queensland Government Department of Agriculture and Fisheries Media. Retrieved from https://www. daf.qld.gov.au/business-priorities/animal-industries/pigs/pig-health-anddiseases/a-z-pig-diseases/swine-brucellosis

Gardner, D., and Reichel, M. (1997). No evidence of Brucella canis infection in New Zealand dogs. Surveillance 24, 17-18.

Hofer, E., Bag, Z. N., Revilla-Fernandez, S., Melzer, F., Tomaso, H., Lopez-Goni, I., et al. (2012). First detection of Brucella canis infections in a breeding kennel in Austria. New Microbiol. 35, 507-510. Available online at: http://www. newmicrobiologica.org/PUB/allegati_pdf/2012/4/507.pdf

James, D. R., Golovsky, G., Thornton, J. M., Goodchild, L., Havlicek, M., Martin, P., et al. (2017). Clinical management of Brucella suis infection in dogs and implications for public health. Aust. Vet. J. 95, 19-25. doi: 10.1111/avj. 12550

Mor, S. M., Wiethoelter, A. K., Lee, A., Moloney, B., James, D. R., and Malik, R. (2016). Emergence of Brucella suis in dogs in New South Wales, Australia: clinical findings and implications for zoonotic transmission. BMC Vet. Res. 12:199. doi: 10.1186/s12917-016-0835-0 to correct inaccurate statements such as those made by Moreno (2014).

\section{AUTHOR CONTRIBUTIONS}

CK identified the error and wrote the commentary with input from SM, RM, and AW. All authors critically reviewed and approved the final version.

Moreno, E. (2014). Retrospective and prospective perspectives on zoonotic brucellosis. Front. Microbiol. 5:213. doi: 10.3389/fmicb.201 4.00213

Rogers, R. J., Cook, D. R., Ketterer, P. J., Baldock, F. C., Blackall, P. J., and Stewart, R. W. (1989). An evaluation of three serological tests for Brucella suis in pigs. Aust. Vet. J. 66, 77-80. doi: 10.1111/j.1751-0813.1989.tb09748.x

Scholz, H. C., Hofer, E., Vergnaud, G., Fleche, P. L., Whatmore, A. M., Dahouk, S. A., et al. (2009). Isolation of Brucella microti from mandibular lymph nodes of red foxes, vulpes vulpes, in lower Austria. VectorBorne Zoonotic Dis. 9, 153-156. doi: $10.1089 /$ vbz.2008.0036

Tiller, R. V., Gee, J. E., Frace, M. A., Taylor, T. K., Setubal, J. C., Hoffmaster, A. R., et al. (2010). Characterization of novel Brucella strains originating from wild native rodent species in North Queensland, Australia. Appl. Environ. Microbiol. 76, 5837-5845. doi: 10.1128/AEM.00620-10

Wattam, A. R., Inzana, T. J., Williams, K. P., Mane, S. P., Shukla, M., Almeida, N. F., et al. (2012). Comparative genomics of early-diverging Brucella strains reveals a novel lipopolysaccharide biosynthesis pathway. mBio 3:e00246-12. doi: $10.1128 / \mathrm{mBio} .00246-12$

Conflict of Interest Statement: The authors declare that the research was conducted in the absence of any commercial or financial relationships that could be construed as a potential conflict of interest.

Copyright $(2019$ Kneipp, Malik, Mor and Wiethoelter. This is an open-access article distributed under the terms of the Creative Commons Attribution License (CC BY). The use, distribution or reproduction in other forums is permitted, provided the original author(s) and the copyright owner(s) are credited and that the original publication in this journal is cited, in accordance with accepted academic practice. No use, distribution or reproduction is permitted which does not comply with these terms. 